\title{
SOME EFFECTS OF INTRAVENOUSLY ADMINISTERED CALCIUM ON INORGANIC PHOSPHATE METABOLISM
}

\author{
By HOWARD H. HIATT 1 AND DAVID D. THOMPSON 2 \\ (From the National Institute of Arthritis and Metabolic Diseases, National Institutes of Health, \\ Public Health Service, U. S. Department of Health, Education and Welfare, \\ Bethesda, Md.)
}

(Submitted for publication August 30, 1956; accepted December 13, 1956)

A reduction of urinary phosphate follows the intravenous infusion of calcium in normal individuals (1-3). The fall in phosphate excretion has been ascribed to an inhibition of parathyroid function by the elevated plasma calcium level $(2,3)$.

A decrease in renal tubular reabsorption of phosphate following the administration of parathyroid extract has been demonstrated (4). Therefore, variations in endogenous parathyroid secretion may be expected to result in changes in phosphate reabsorption by the tubule. If the depression of $\mathrm{P}^{8}$ excretion following the infusion of calcium is the result of an inhibition of parathyroid activity, it should be accompanied by an increase in $\mathrm{P}$ reabsorption by the renal tubule. Such a phenomenon was demonstrated in renal function studies carried out during and immediately following calcium infusions. One might anticipate, further, that alterations in the level of circulating parathyroid hormone would affect the usual response of urinary $\mathrm{P}$ to calcium administration. Thus, no fall in urinary $\mathrm{P}$ was observed by Howard, Hopkins, and Connor in profoundly hypoparathyroid patients given calcium infusions (3). This observation has been confirmed by our studies. The maintenance of a constant level of circulating parathyroid hormone by the daily administration of a fixed quantity of extract might also be expected to abolish the $\mathrm{P}$ response to $\mathrm{Ca}$ infusions in normal subjects. This hypothesis, too, was confirmed in the studies to be reported.

\footnotetext{
1 Present address : Department of Medicine, Harvard Medical School and Beth Israel Hospital, Boston, Massachusetts.

2 Present address: Department of Physiology, Cornell University Medical College, New York 21, N. Y.

${ }^{8}$ As in the previous papers, the following abbreviations have been used: $\mathrm{Ca}$, calcium; $\mathrm{P}$, inorganic phosphorus; $\mathrm{Tm}$, maximum renal tubular rate of transfer.
}

\section{METHODS}

Most of the subjects and methods employed in this study were described in a previous paper (5). Additional subjects included: R. B., a 22-year-old normal volunteer; T. R., a 70-year-old male with paralysis agitans; E. S., a 7-year-old girl with osteogenesis imperfecta; and V. M., a 40-year-old woman with osteitis deformans and rheumatoid arthritis.

Except where otherwise noted, the studies were carried out with the patients on constant diets containing $130 \mathrm{mg}$. of $\mathrm{Ca}$ and $600 \mathrm{mg}$. of P. The diets were fed for at least three days before control blood and urine collections were begun.

Urine was collected at the intervals indicated and refrigerated until analyses were performed. The completeness of urine collections was checked on all samples by creatinine determinations, carried out according to the method of Bonsnes and Taussky (6).

Calcium in an amount of $15 \mathrm{mg}$. per kilogram of body weight was administered intravenously as the gluconate salt, dissolved in $1000 \mathrm{ml}$. of 0.9 per cent saline over a four-hour period, generally from 8 a.m. to $12 \mathrm{~m}$.

Heparinized venous blood samples for determinations of plasma $\mathrm{Ca}$ and $\mathrm{P}$ were obtained, one in the fasting state before the infusion was begun, and another at the conclusion of the infusion, before the subject was given lunch, and at least three hours after breakfast. Urine was generally collected in 4,8 , or 12-hour aliquots on one or more days prior to, and on the day following, as well as on the day of the $\mathrm{Ca}$ infusion. No ill effects were noted in the patients receiving calcium infusions. The studies of renal function and the administration of parathyroid extract were carried out as described in earlier papers $(4,5)$.

\section{RESULTS}

\section{Effects of Ca infusions on $P$ excretion in normal subjects}

In 33 studies in 9 subjects with normal parathyroid function, a 4-hour infusion containing 15 $\mathrm{mg}$. of Ca per kilogram of body weight led to a fall in the 24-hour urinary $P$ excretion of 9 to 71 per cent. The decrease in urinary $\mathrm{P}$ was most pronounced during the 8 to 24 hours following the start of the $\mathrm{Ca}$ infusion. In most subjects a rise 


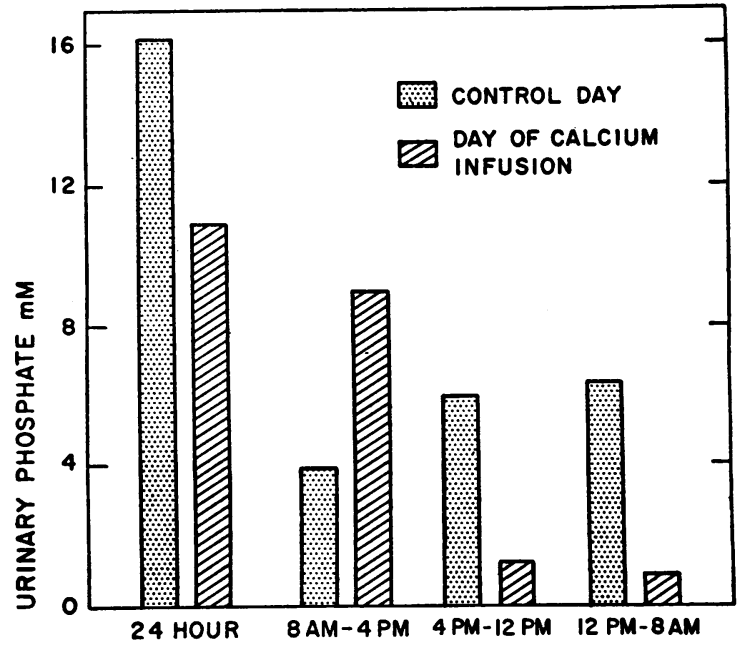

Fig. 1. The Effects of Intravenous Calcium on the Urinary Excretion of Phosphate in R. H., a Normal Subject

The calcium was infused from 8 a.m. to $12 \mathrm{~m}$.

in $\mathrm{P}$ excretion was observed during the 4 hours in which $\mathrm{Ca}$ was infused, and in several subjects this increase continued during the four hours following the completion of the $\mathrm{Ca}$ infusion (Figure 1). Hence the inhibitory effect of the calcium infusion on urinary $P$ was actually greater than was apparent from a measurement of only the total 24 hour $\mathrm{P}$ excretion.

\section{Effects of $C a$ infusions on $P$ excretion in patients with parathyroid disease}

In the only subject with profound hypoparathyroidism studied the infusion of calcium on four occasions led to a marked rise in $\mathrm{P}$ excretion, not only during the $\mathrm{Ca}$ infusion, as in normal subjects, but throughout the remainder of the 24-hour period (Figure 2). One subject who had mild, but unequivocal clinical and laboratory manifestations of hypoparathyroidism had a decrease in urinary $\mathrm{P}$ excretion following a calcium infusion (Figure 3 ). In this subject no significant change in $\mathrm{P}$ excretion was observed upon examination of only the data for the entire 24 -hour period. The fall in urinary $P$ during the period from 11 p.m. to 8 a.m., however, was unequivocal, and far greater than spontaneous variations observed in this patient's $\mathrm{P}$ excretion on several successive days during which no calcium infusions were given. A patient with hyperparathyroidism, later found to

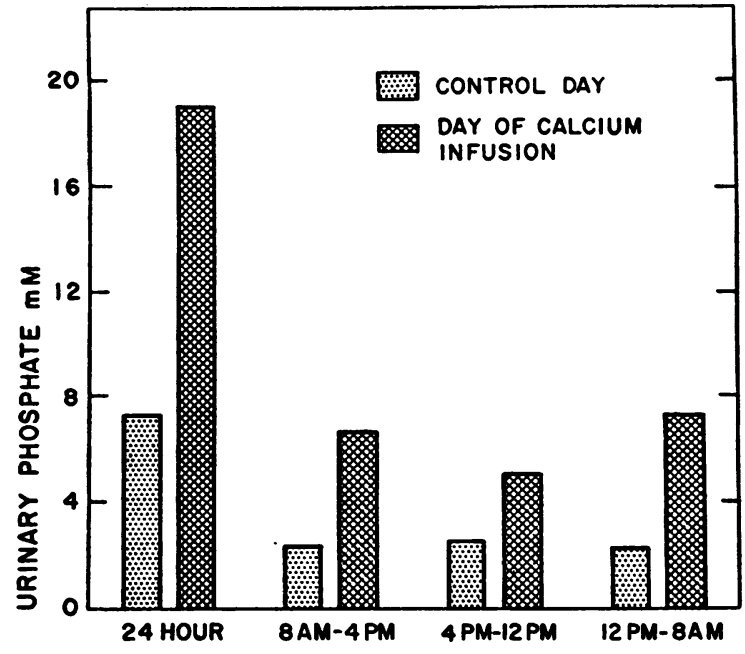

Fig. 2. The Effects of Intratenous Calcium on the Urinary Excretion of Phosphate in A. W., a Patient with Profound Hypoparathyroidism

The calcium was infused from 8 a.m. to $12 \mathrm{~m}$.

have a parathyroid adenoma, had no change in urinary $\mathrm{P}$ following a calcium infusion.

\section{Effect of dietary intake on the response of $P$ ex- cretion to $\mathrm{Ca}$ infusions}

All of the studies reported above and many of those described in the literature were carried out with the subjects on constant diets containing small quantities of $\mathrm{Ca}$ and $\mathrm{P}$. Changes in the intake of these minerals were shown to have no qualitative influence on the decrease in urinary $P$ which followed $\mathrm{Ca}$ infusions (Table I). In most subjects, however, the fall in urinary $\mathrm{P}$ relative to the excretion on the control day was more striking on the low Ca-low $\mathrm{P}$ diet than when the intake of $\mathrm{Ca}$ or $\mathrm{P}$ was increased. Variations in urinary $P$ when the intake of this mineral was inconstant were so great that no conclusions could be drawn concerning the influence of $\mathrm{Ca}$ infusions under such conditions. Of interest is the fact that an increase in dietary $\mathrm{Ca}$ while the intake of $\mathrm{P}$ was held constant led to a sustained fall in urinary $P$ comparable to that seen following the intravenous administration of $\mathrm{Ca}$ (Table I, C. H., R. H.). Complete metabolic balance studies indicated that the increase in $\mathrm{Ca}$ intake resulted in an increased $\mathrm{P}$ storage, rather than a shift of $\mathrm{P}$ from urine to the stools. 
TABLE I

Effects of calcium infusions on plasma and urinary phosphate at different dietary levels of calcium and phosphorus

\begin{tabular}{|c|c|c|c|c|c|c|c|}
\hline \multirow[b]{2}{*}{ Subject } & \multirow[b]{2}{*}{ Date } & \multicolumn{2}{|c|}{ Intake } & \multicolumn{2}{|c|}{ Plasma P } & \multicolumn{2}{|c|}{ Urine $\mathbf{P}$} \\
\hline & & $\begin{array}{c}\text { Calcium } \\
\text { mg. }\end{array}$ & $\begin{array}{l}\text { Phosphorus } \\
\text { mg. }\end{array}$ & $\begin{array}{c}\text { Before } \\
\mu M / m l .\end{array}$ & $\begin{array}{c}\text { After } \\
\mu M / m b .\end{array}$ & $\begin{array}{c}\text { Control } \\
m M / 24 \mathrm{hr} .\end{array}$ & $\frac{\text { Exp'tal }}{m M / 24 h o s}$ \\
\hline C. H. & $\begin{array}{r}6 / 2 / 54 \\
9 / 11 / 54 \\
12 / 18 / 54 \\
2 / 8 / 55\end{array}$ & $\begin{array}{r}130 \\
130 \\
130 \\
1,200\end{array}$ & $\begin{array}{l}600 \\
600 \\
600 \\
600\end{array}$ & $\begin{array}{l}1.25 \\
1.16 \\
1.21\end{array}$ & $\begin{array}{l}1.57 \\
1.60 \\
1.54\end{array}$ & $\begin{array}{l}24.1 \\
21.2 \\
17.4 \\
10.0\end{array}$ & $\begin{array}{r}10.0 \\
6.1 \\
8.3 \\
5.1\end{array}$ \\
\hline R. H. & $\begin{array}{r}10 / 13 / 54 \\
2 / 5 / 55 \\
3 / 9 / 55\end{array}$ & $\begin{array}{r}130 \\
1,500 \\
130\end{array}$ & $\begin{array}{r}600 \\
600 \\
1,600\end{array}$ & $\begin{array}{l}1.27 \\
1.00 \\
1.09\end{array}$ & $\begin{array}{l}1.53 \\
1.11 \\
1.55\end{array}$ & $\begin{array}{c}15.2 \\
3.7 \\
41\end{array}$ & $\begin{array}{l}8.4 \\
1.5 \\
29\end{array}$ \\
\hline W. R. & $\begin{array}{r}9 / 21 / 54 \\
11 / 15 / 54\end{array}$ & $\begin{array}{l}130 \\
200\end{array}$ & $\begin{array}{r}600 \\
1,500\end{array}$ & $\begin{array}{l}1.16 \\
0.86\end{array}$ & $\begin{array}{l}1.65 \\
1.34\end{array}$ & $\begin{array}{l}20 \\
40\end{array}$ & $\begin{array}{l}14 \\
33\end{array}$ \\
\hline V. M. & $\begin{array}{r}12 / 6 / 54 \\
12 / 10 / 54 \\
12 / 17 / 54\end{array}$ & $\begin{array}{l}130 \\
130 \\
130\end{array}$ & $\begin{array}{r}600 \\
600 \\
1,800\end{array}$ & $\begin{array}{l}1.08 \\
1.00 \\
1.19\end{array}$ & $\begin{array}{l}1.31 \\
0.87 \\
1.14\end{array}$ & $\begin{array}{r}9.8 \\
10.9 \\
30.8\end{array}$ & $\begin{array}{r}5.7 \\
7.7 \\
24.4\end{array}$ \\
\hline D. F. & & 610 & 1,015 & 1.05 & 1.58 & 27 & 24 \\
\hline
\end{tabular}

Effect of administration of parathyroid extract on the response of $P$ excretion to $C a$ infusions

The fall in urinary $P$ during calcium infusions in normal subjects and the absence of such a phenomenon in severely hypoparathyroid individuals have led to the postulate that the decrease in $\mathrm{P}$ excretion results from a diminution of parathyroid secretion. To test this hypothesis parathyroid extract was administered at several dosage levels to normal subjects. After the completion of one or more control studies, parathyroid extract was given at each dosage level until the 24-hour urinary excretion of $\mathrm{P}$ was reasonably constant and continued through the day on which the calcium was infused. It was reasoned that if the decrease in urinary $P$ were the result of an inhibition of parathyroid secretion, a $\mathrm{Ca}$ infusion should have no effect on $\mathrm{P}$ excretion in a subject receiving a constant amount of exogenous parathyroid extract. Such was found to be the case, the effect of $\mathrm{Ca}$ infusions on $\mathrm{P}$ excretion becoming progressively less with increasing dosage of parathyroid extract, and finally disappearing when the patient was receiving 300 units of parathyroid extract daily (Figure 4). (Why the urinary $P$ excretion in the study described in Figure 4 was lower with the subject receiving 300 units of parathyroid extract daily than with 200 units is not known. The same lot of parathyroid was used, and the serum $\mathrm{Ca}$ at the 300-unit level was 11.45 mg. per cent, as compared with 10.00 at 200 units.)
A similar phenomenon was observed in 4 other subjects (Table II). The daily administration of 200 units of parathyroid extract to the subject with severe hypoparathyroidism led to a restoration to normal of the plasma and urinary $\mathrm{Ca}$ and $P$, but had no effect on the profound increase in $\mathrm{P}$ excretion observed in this subject in response to $\mathrm{Ca}$ infusions.

\section{Effect of Ca infusions on plasma $P$}

The intravenous infusion of $\mathrm{Ca}$ led to an increase of up to 50 per cent in the plasma $\mathrm{P}$ in al-

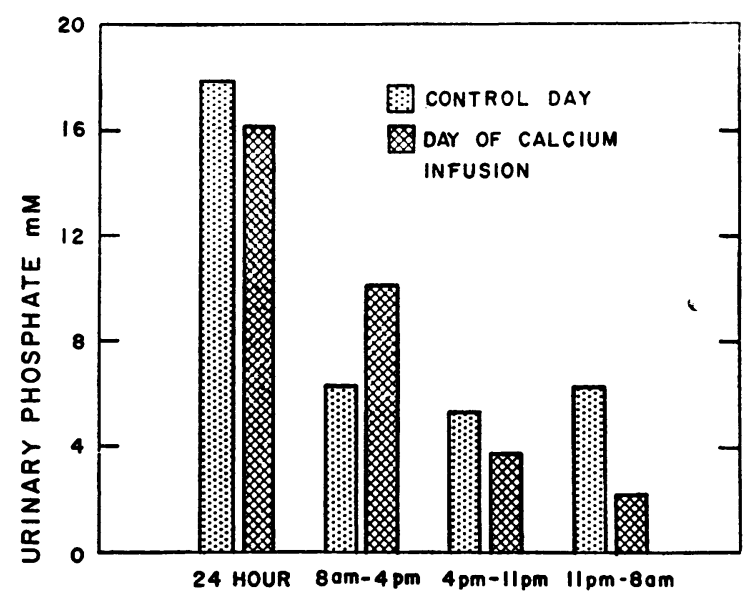

Fig. 3. The Effects of Intravenous Calcium on the Urinary Excretion of Phosphate in L. D., a Patient with Mild Hypoparathyroidism

The calcium was infused from 8 a.m. to $12 \mathrm{~m}$. 
TABLE II

Effects of calcium infusions on plasma and urinary phosphate under influence of parathyroid extract

\begin{tabular}{|c|c|c|c|c|c|c|c|c|}
\hline \multirow[b]{2}{*}{ Subject } & \multirow[b]{2}{*}{ Date } & \multicolumn{2}{|c|}{ Parathyroid extract } & \multirow{2}{*}{$\begin{array}{c}\text { Plasma Ca } \\
\text { mg. per } \\
\text { cent }\end{array}$} & \multicolumn{2}{|c|}{ Plasma P } & \multicolumn{2}{|c|}{ Urine $\mathbf{P}$} \\
\hline & & units/day & days & & $\begin{array}{c}\text { Before } \\
\boldsymbol{\mu M} / \boldsymbol{m l} \text {. }\end{array}$ & $\underset{\mu M / m l .}{\text { After }}$ & $\begin{array}{l}\text { Control } \\
m M / 24 h r\end{array}$ & $\underset{m M}{\operatorname{Exp} p^{\prime t a l}}$ \\
\hline C. H. & $\begin{array}{r}12 / 18 / 54 \\
11 / 12 / 54 \\
7 / 2 / 54\end{array}$ & $\begin{array}{r}0 \\
200 \\
2,000\end{array}$ & $\begin{array}{l}6 \\
1\end{array}$ & $\begin{array}{r}9.81 \\
9.00 \\
12.23\end{array}$ & $\begin{array}{l}1.16 \\
1.33 \\
1.11\end{array}$ & $\begin{array}{l}1.60 \\
1.47 \\
1.48\end{array}$ & $\begin{array}{l}17 \\
18 \\
44\end{array}$ & $\begin{array}{r}8 \\
17 \\
62\end{array}$ \\
\hline W. R. & $\begin{array}{r}9 / 21 / 54 \\
5 / 9 / 55\end{array}$ & $\begin{array}{r}0 \\
1,500\end{array}$ & 3 & $\begin{array}{l}10.35 \\
13.87\end{array}$ & $\begin{array}{l}1.16 \\
0.95\end{array}$ & $\begin{array}{l}1.65 \\
0.51\end{array}$ & $\begin{array}{l}20 \\
58\end{array}$ & $\begin{array}{l}14 \\
64\end{array}$ \\
\hline V. M. & $\begin{array}{r}12 / 6 / 54 \\
12 / 13 / 54\end{array}$ & $\begin{array}{r}0 \\
200\end{array}$ & 4 & $\begin{array}{r}9.50 \\
10.25\end{array}$ & $\begin{array}{l}1.00 \\
0.99\end{array}$ & $\begin{array}{l}0.87 \\
0.99\end{array}$ & $\begin{array}{l}10.9 \\
12.8\end{array}$ & $\begin{array}{r}7.7 \\
12.0\end{array}$ \\
\hline E. P. & $\begin{array}{l}5 / 17 / 55 \\
3 / 24 / 55\end{array}$ & $\begin{array}{r}0 \\
600\end{array}$ & 4 & $\begin{array}{l}10.30 \\
13.15\end{array}$ & $\begin{array}{l}1.24 \\
0.95\end{array}$ & $\begin{array}{l}1.43 \\
1.14\end{array}$ & $\begin{array}{l}19.9 \\
34\end{array}$ & $\begin{array}{l}11.9 \\
34\end{array}$ \\
\hline
\end{tabular}

most all of the subjects studied (Tables I and II). The plasma $\mathrm{P}$ reached its maximum level at the completion of the $\mathrm{Ca}$ infusion and was usually still elevated 8 to 16 hours later, even when the plasma $\mathrm{Ca}$ had returned to its control level. The increase in plasma $\mathrm{P}$ bore no constant relationship to changes in $\mathrm{P}$ excretion. It was as great in the hypoparathyroid subject whose urinary $P$ increased following the $\mathrm{Ca}$ infusion as it was in most of the normal subjects. No increase in plasma $P$ was seen on several occasions in V. M., a patient with osteitis deformans, and in some, but not all of the normal subjects rendered hyperparathyroid by the administration of parathyroid extract (Table II).

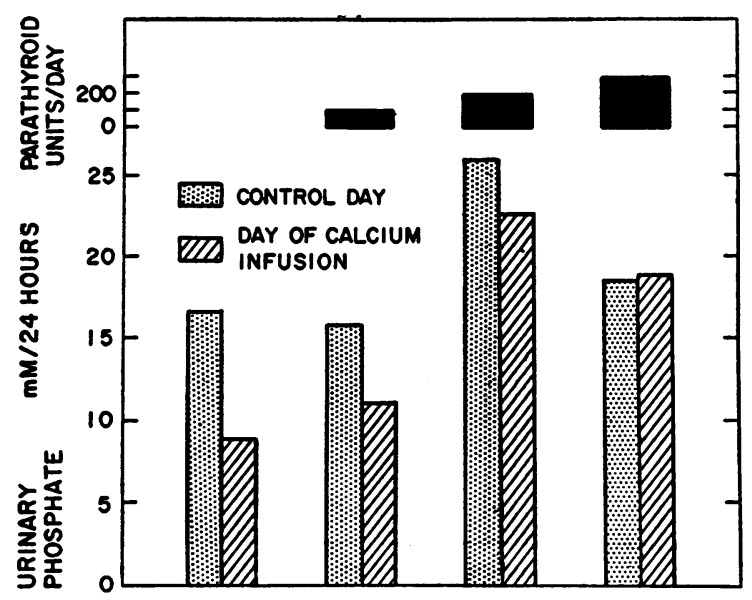

Fig. 4. The Influence of Several Dosage Levels of Parathyrom Extract on the Response of the Urinary $P$ to Ca Infusions in $R$. H., a Normal Subject

\section{Effects of $\mathrm{Ca}$ infusions on renal function}

To investigate further the mechanism of the changes in phosphate excretion resulting from $\mathrm{Ca}$ infusions, renal clearance studies were carried out before, during, and after such infusions in normal subjects. Phosphate excretion in one subject was found to be $20 \mu \mathrm{M}$ per minute prior to, $25 \mu \mathrm{M}$ per minute during, and $7 \mu \mathrm{M}$ per minute 16 hours following a calcium infusion (Table III). The rise in $\mathrm{P}$ excretion during the $\mathrm{Ca}$ infusion was found to be the result of an increase in filtered phosphate, which, in turn, was consequent to a rise in plasma phosphate. The reabsorbed phosphate was shown to be increased during the $\mathrm{Ca}$ infusion. Sixteen hours following the infusion the filtered phosphate was still considerably higher than the pre-infusion level, again as a result of an increased plasma phosphate (which had not yet returned to its control value). At this time since the tubular reabsorption of $P$ remained high, there was a fall in the excretion of $P$.

Because the $\mathrm{Ca}$ infusions led to a rise in plasma $P$, the aforementioned studies did not permit an assessment of renal tubular reabsorption under conditions of equal filtered loads of phosphate. Hence, similar studies were carried out, but with the intravenous administration of enough phosphate before and following the $\mathrm{Ca}$ infusion to raise the serum phosphate to the level anticipated during the $\mathrm{Ca}$ infusion (Table IV, Figure 5). In the study of R. H. (Table IV) it is clear that at equivalent loads of filtered $P$ approximately 40 per cent more $P$ was reabsorbed during, and 16 
TABLE III

Patterns of renal excretion of phosphate before $(A)$, during $(B)$, and after $(C)$ infusion of calcium *

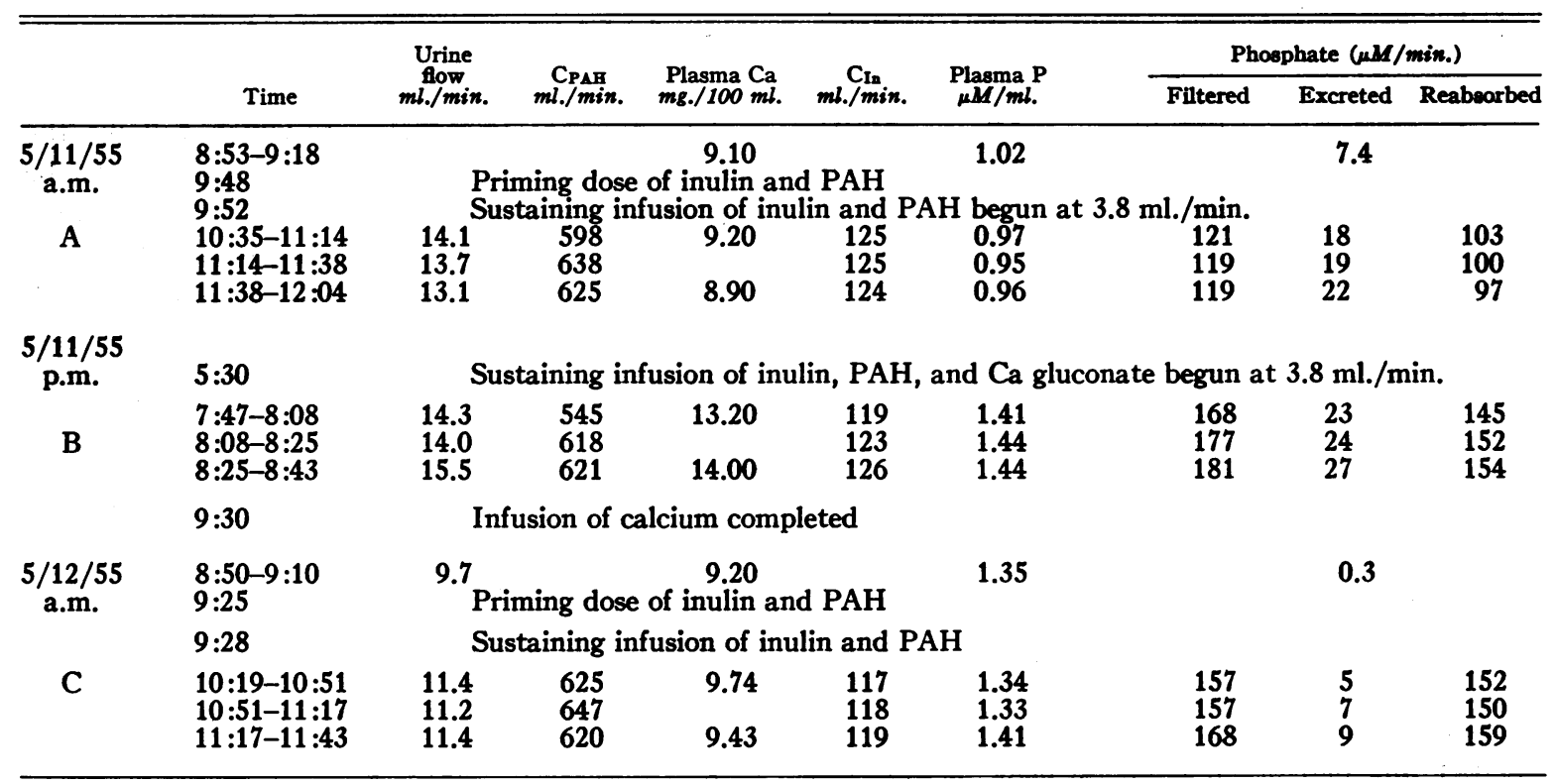

* R. H., normal female.

hours following a Ca infusion than during the con- parable filtered $\mathrm{P}$ loads, the $\mathrm{P}$ excretion is less trol period. The excretion of phosphate during during the $\mathrm{Ca}$ infusion than during the control the $\mathrm{Ca}$ infusion was increased over the control periods ( $26 \mu \mathrm{M}$ per minute as compared with 76). (26 $\mu \mathrm{M}$ per minute vs. 12). However, at com- Indeed, a rise in $\mathrm{P}$ reabsorption occurred during

TABLE IV

Patterns of renal excretion of phosphate before $(A)$, during $(B)$, and after $(C)$ infusion of calcium *

\begin{tabular}{|c|c|c|c|c|c|c|c|c|}
\hline & \multirow[b]{2}{*}{ Time } & \multirow{2}{*}{$\begin{array}{l}\text { Urine } \\
\text { flow } \\
\text { mb./min. }\end{array}$} & \multirow{2}{*}{ 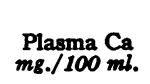 } & \multirow{2}{*}{$\underset{m b . / m i n .}{C_{I_{n}}}$} & \multirow{2}{*}{$\underset{\mu M / m b .}{\text { Plasma P }}$} & \multicolumn{3}{|c|}{ Phosphate (uM/min.) } \\
\hline & & & & & & Filtered & Excreted & Reabsorbed \\
\hline \multirow{3}{*}{$\begin{array}{l}6 / 23 \\
\text { a.m. }\end{array}$} & $9: 00-9: 30$ & & 9.22 & $(118) \dagger$ & 1.02 & (120) & 12 & (108) \\
\hline & $\begin{array}{l}y: 00 \\
10: 00\end{array}$ & \multicolumn{7}{|c|}{$\begin{array}{l}\text { Priming dose of inulin } \\
\text { Begin sustaining infusion containing inulin and } 30 \mu \mathrm{M} \mathrm{Na} \text { phosphate } / \mathrm{ml} \text {. } \\
\text { at } 3.8 \mathrm{ml} . / \mathrm{min} \text {. }\end{array}$} \\
\hline & $\begin{array}{l}11: 00-11: 35 \\
11: 35-12: 13 \\
12: 13-12: 35\end{array}$ & $\begin{array}{r}10.6 \\
9.4 \\
10.5\end{array}$ & & $\begin{array}{l}119 \\
121 \\
116\end{array}$ & $\begin{array}{l}1.42 \\
1.53 \\
1.59\end{array}$ & $\begin{array}{l}168 \\
185 \\
185\end{array}$ & $\begin{array}{l}54 \\
73 \\
79\end{array}$ & $\begin{array}{l}114 \\
112 \\
106\end{array}$ \\
\hline \multirow[t]{2}{*}{$\begin{array}{l}6 / 23 \\
\text { P.m. } \\
\text { B }\end{array}$} & $\begin{array}{l}5: 25 \\
5: 30\end{array}$ & \multicolumn{7}{|c|}{$\begin{array}{l}\text { Begin sustaining infusion containing inulin and } \mathrm{Ca} \text { gluconate } \\
\text { at } 3.8 \mathrm{ml} . / \mathrm{min} \text {. }\end{array}$} \\
\hline & $\begin{array}{l}8: 00-8: 20 \\
8: 20-8: 42 \\
8: 42-9: 30\end{array}$ & $\begin{array}{l}14.1 \\
14.6 \\
14.8\end{array}$ & $\begin{array}{l}11.05 \\
11.85\end{array}$ & $\begin{array}{l}109 \\
119 \\
118\end{array}$ & $\begin{array}{l}1.50 \\
1.50 \\
1.65\end{array}$ & $\begin{array}{l}164 \\
179 \\
191\end{array}$ & $\begin{array}{l}23 \\
26 \\
28\end{array}$ & $\begin{array}{l}141 \\
153 \\
163\end{array}$ \\
\hline \multirow{3}{*}{$\begin{array}{l}6 / 24 \\
\text { a.m. }\end{array}$} & $\begin{array}{l}9: 00-9: 30 \\
0: 44\end{array}$ & 9.41 & 9.21 & $(117) \dagger$ & 1.36 & (159) & 4 & (155) \\
\hline & $\begin{array}{l}9: 44 \\
9: 47\end{array}$ & \multicolumn{7}{|c|}{$\begin{array}{l}\text { Priming dose of inulin } \\
\text { Begin sustaining infusion containing inulin and } 15 \mu \mathrm{M} \text { Na phosphate } / \mathrm{ml} \text {. } \\
\text { at } 3.8 \mathrm{ml} . / \mathrm{min} \text {. }\end{array}$} \\
\hline & $\begin{array}{l}11: 20-11: 46 \\
11: 46-12: 09\end{array}$ & $\begin{array}{r}9.7 \\
10.3\end{array}$ & 8.76 & $\begin{array}{l}118 \\
115\end{array}$ & $\begin{array}{l}1.60 \\
1.62\end{array}$ & $\begin{array}{l}189 \\
186\end{array}$ & $\begin{array}{l}39 \\
44\end{array}$ & $\begin{array}{l}150 \\
142\end{array}$ \\
\hline
\end{tabular}

* R. H., normal female.

$\uparrow$ Not measured; average of succeeding periods. 


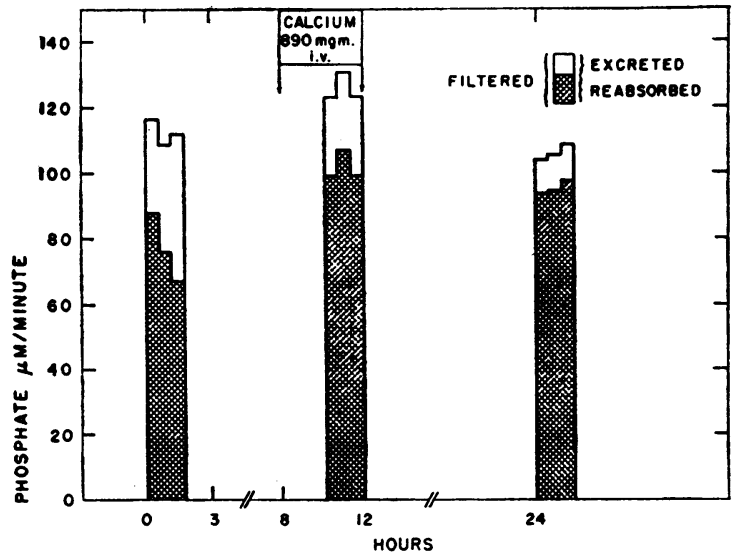

Fig. 5. Filtered, Reabsorbed, and Excreted Phosphate Before, During, and Following the Infusion of Ca to E. P., a Normal Female

the $\mathrm{Ca}$ infusion. Sixteen hours later the plasma $\mathrm{P}$, although not yet back to its control level, 1.02 $\mu \mathrm{M}$ per ml., had fallen from its peak of $1.65 \mu \mathrm{M}$ per ml. to $1.36 \mu \mathrm{M}$ per $\mathrm{ml}$. The consequent decrease in filtered load along with the still-elevated reabsorbed phosphate resulted in a marked reduction in the excretion of $P$.

\section{Calcium retention}

The portion of the intravenously administered calcium retained was considered to be the difference between the amount of calcium administered and the increase in urinary calcium on the day of the calcium infusion over the excretion on the previous day. Since fecal calcium was not measured during these studies, the figure for calcium retention is only approximate; previous work, however, has indicated that only a small proportion of intravenously administered calcium appears in the stool (7). The calcium retention approximated 70 per cent of the administered dose in 4 of 5 subjects without parathyroid disease (Table $\mathrm{V})$. In all subjects the fraction of calcium retained was remarkably constant when determined on more than one occasion, even several months apart. The low urinary excretion and high retention of $\mathrm{Ca}$ by $\mathrm{A}$. W. was undoubtedly ascribable to the low baseline level of plasma Ca. In this individual, the $\mathrm{Ca}$ infusion led to a rise in plasma $\mathrm{Ca}$ from approximately $7.0 \mathrm{mg}$. per cent to $10 \mathrm{mg}$. per cent. Hence, the filtered load of calcium was undoubtedly lower than that occurring in normal individuals.

\section{DISCUSSION}

The decrease in urinary $\mathrm{P}$ which follows the intravenous administration of $\mathrm{Ca}$ appears to be mediated by the parathyroids. We have confirmed the reports of others $(3,8)$ that markedly hypoparathyroid subjects respond to $\mathrm{Ca}$ infusions with an increase in urinary $P$. In addition, we have observed the abolition of the usual response to $\mathrm{Ca}$ infusions in normal subjects by the administration of parathyroid extract. The amount of extract required to achieve this end was surprisingly large; in one subject $\mathrm{P}$ excretion was inhibited by $\mathrm{Ca}$ infusions until a daily dosage of 300 units was reached. We had postulated that the response to $\mathrm{Ca}$ would disappear upon the administration of an amount of extract approximating the endogenous parathyroid secretion. On the basis of maintenance requirements of patients with hypoparathyroidism, we had estimated this figure to be considerably less than 300 units daily.

Our data support the advice that studies of the influence of $\mathrm{Ca}$ on $\mathrm{P}$ excretion be done only after at least three days on a diet constant in calcium and phosphorus content, and preferably low in these minerals. All of our subjects, normal, hypoparathyroid, and those with induced hyperparathyroidism, showed a rise in urinary $\mathrm{P}$ during the period of $\mathrm{Ca}$ infusion. Hence, if this procedure be employed as a measure of parathyroid function, its usefulness would be increased by collecting urine during the period 8 to 24 hours following the start of a four-hour $\mathrm{Ca}$ infusion, and during a corresponding period on the control day. Since our subject with mild hypoparathyroidism showed a "normal" response to $\mathrm{Ca}$ administration, it is unlikely that this test can be considered a sensitive index of parathyroid insufficiency.

Whether the level of serum $\mathrm{Ca}$ governs parathyroid secretion remains unknown. No detectable change in serum level occurred in patients whose dietary $\mathrm{Ca}$ was increased, but a profound and sustained fall in $\mathrm{P}$ excretion followed. The apparent relationship of serum or dietary $\mathrm{Ca}$ to parathyroid secretion does not, of course, preclude the possibility that other factors influence both parathyroid function and phosphate transport by the renal 
TABLE V

Effect of calcium infusions on urinary calcium

\begin{tabular}{|c|c|c|c|c|c|}
\hline \multirow[b]{2}{*}{ Subject } & \multirow[b]{2}{*}{ Date } & \multirow{2}{*}{$\begin{array}{c}\text { Calcium } \\
\text { infused } \\
m g .\end{array}$} & \multicolumn{2}{|c|}{$\begin{array}{c}\text { Urinary calcium } \\
\text { mg./24 hours }\end{array}$} & \multirow{2}{*}{$\underset{\%}{\text { Administered }} \mathrm{C}$} \\
\hline & & & Control & $\begin{array}{c}\text { Day of Ca } \\
\text { infusion }\end{array}$ & \\
\hline $\begin{array}{l}\text { C. H. } \\
\text { (Normal) }\end{array}$ & $\begin{array}{r}6 / 54 \\
9 / 54 \\
11 / 54\end{array}$ & $\begin{array}{l}975 \\
982 \\
982\end{array}$ & $\begin{array}{r}121 \\
89 \\
90\end{array}$ & $\begin{array}{l}411 \\
335 \\
403\end{array}$ & $\begin{array}{l}70 \\
75 \\
68\end{array}$ \\
\hline $\begin{array}{l}\text { W. R. } \\
\text { (Normal) }\end{array}$ & $11 / 54$ & 982 & 125 & 481 & 64 \\
\hline $\begin{array}{l}\text { R. H. } \\
\text { (Normal) }\end{array}$ & $\begin{array}{r}10 / 54 \\
10 / 54 \\
1 / 55 \\
1 / 55\end{array}$ & $\begin{array}{l}980 \\
980 \\
890 \\
890\end{array}$ & $\begin{array}{r}63 \\
104 \\
94 \\
125\end{array}$ & $\begin{array}{l}610 \\
670 \\
547 \\
580\end{array}$ & $\begin{array}{l}44 \\
43 \\
49 \\
49\end{array}$ \\
\hline $\begin{array}{l}\text { D. F. } \\
\text { (Normal) }\end{array}$ & $1 / 55$ & 1,250 & 38 & 358 & 74 \\
\hline $\begin{array}{c}\text { V. M. } \\
\text { (Osteitis deformans) }\end{array}$ & $\begin{array}{l}12 / 55 \\
12 / 55 \\
12 / 55 \\
12 / 55^{*}\end{array}$ & $\begin{array}{l}515 \\
515 \\
515 \\
515\end{array}$ & $\begin{array}{r}90 \\
111 \\
73 \\
168\end{array}$ & $\begin{array}{l}229 \\
185 \\
204 \\
324\end{array}$ & $\begin{array}{l}75 \\
66 \\
74 \\
70\end{array}$ \\
\hline $\begin{array}{c}\text { A. W. } \\
\text { (Hypoparathyroid) }\end{array}$ & $\begin{array}{l}9 / 54 \\
1 / 55 \\
2 / 55\end{array}$ & $\begin{array}{l}960 \\
890 \\
890\end{array}$ & $\begin{array}{l}59 \\
20 \\
62\end{array}$ & $\begin{array}{r}181 \\
72 \\
96\end{array}$ & $\begin{array}{l}87 \\
91 \\
95\end{array}$ \\
\hline
\end{tabular}

* On 200 units of parathyroid extract daily.

tubule. Indeed, a profound depression of TmP was demonstrated following the intravenous administration of large quantities of $\mathrm{P}$, and this phenomenon was not reversed by the repeated intravenous administration of $\mathrm{Ca}(9)$.

The mechanism of the increase in plasma $\mathrm{P}$ which follows a rise in serum $\mathrm{Ca}$ has not been demonstrated in these studies. It is clear, however, that it is not dependent on the integrity of the parathyroids, and that it is independent of changes in the urinary excretion of $\mathrm{P}$. Evidence that the elevation of serum $\mathrm{Ca}$ leads to a shift of $P$ from the cells has been advanced by Chen and Neuman (10).

Our studies demonstrate that the rise in urinary $\mathrm{P}$ seen during a $\mathrm{Ca}$ infusion reflects an increase in filtered $\mathrm{P}$, in turn the result of the rise in plasma $P$. Of interest is the observation that the reabsorbed $\mathrm{P}$ reached its maximal level within three hours after the start of the $\mathrm{Ca}$ infusion. If the change in tubular transport of $\mathrm{P}$ reflects an inhibition of parathyroid secretion, and if the duration of action of the parathyroid hormone already circulating prior to the $\mathrm{Ca}$ infusion approximates the six hours found to be the case in the dog by Hastings and Huggins (11), then one might have expected phosphate reabsorption to have been unchanged for several hours. There exists the possibility that during the period of the elevated serum $\mathrm{Ca}$ level the rise in reabsorbed $\mathrm{P}$ as measured appears to be higher than it actually is, as a result of the presence of a non-filtrable Ca-P complex. This seems unlikely, however, in light of the ultra-filtrability studies of Hopkins, Howard, and Eisenberg (12), and also because of the close correspondence of the figures for reabsorbed $\mathrm{P}$ during the $\mathrm{Ca}$ infusions and several hours later when the plasma $\mathrm{Ca}$ had returned to normal levels. The increase in tubular reabsorption of $\mathrm{P}$ during the $\mathrm{Ca}$ infusion recalls a similar phenomenon observed by Foulks following the administration of sulfate to dogs (13). In both instances the rise in tubular reabsorption was accompanied by an elevation of serum $P$, and, hence, presumably by a decrease in intracellular $P$. Foulks postulated that a lowered intracellular $\mathrm{P}$ will effect a rise in the quantity of $\mathrm{P}$ reabsorbed by the renal tubules (13).

Schilling and Laszlo (14) have suggested that the avidity of the skeleton for calcium can be estimated from the proportion of an intravenously administered dose of $\mathrm{Ca}$ not appearing in the urine. 
They have found that normal subjects retain approximately 70 per cent of the $\mathrm{Ca}$ infused, while cancer patients with osteolytic processes retain less, and those with osteoblastic metastases retain more. The behaviour of most of our normal subjects corresponded closely to that reported by Schilling and Laszlo, and the response of those subjects tested on more than one occasion showed little variation. The consistently high excretion of the administered Ca by one young normal control subject without evidence of parathyroid or bone disease, however, suggests that this test cannot by itself be used as an index of the presence of bone disease.

\section{SUMMARY}

1. The intravenous administration of calcium gluconate to normal subjects results in a diminution in the urinary excretion of phosphorus. This phenomenon occurs as a result of increased renal tubular reabsorption of phosphate.

2. This effect of administered calcium appears to require normally functioning parathyroid glands, since it is not seen in patients with profound hypoparathyroidism or hyperparathyroidism, and it can be abolished in normal subjects by the prior administration of parathyroid extract.

3 . No change, or even an elevation in P excretion occurs during the administration of calcium. Hence, more striking reductions in $\mathrm{P}$ excretion are detected if urine is collected during the 8 to 24 hours after the four-hour infusion of calcium is begun, and compared with the corresponding period on the control day.

4. The response of urinary $\mathrm{P}$ excretion to calcium administration is not a sensitive test for hypoparathyroidism, since patients with clinically apparent, but mild hypoparathyroidism may show a pattern similar to that of normal subjects.

5. The percentage of administered calcium retained by a given individual is quite constant on repeated testing. However, unexplained variability occurs in the amount retained by different subjects.

6. The intravenous infusion of calcium leads to a prompt rise in plasma phosphate in almost all subjects. The rise occurs before there is any reduction in urinary excretion of $P$, and hence must represent mobilization from intracellular stores. In some individuals large doses of parathyroid extract abolish this elevation of plasma $P$.

\section{ACKNOWLEDGMENTS}

We wish to express our gratitude to Misses Doris Graves and Mary Margaret Brown for their technical assistance.

\section{REFERENCES}

1. Albright, F., and Sulkowitch, H. W., The effect of vitamin $\mathrm{D}$ on calcium and phosphorus metabolism; studies on four patients. J. Clin. Invest., 1938, 17, 305.

2. Baylor, C. H., Van Alstine, H. E., Keutmann, E. H., and Bassett, S. H., The fate of intravenously administered calcium. Effect on urinary calcium and phosphorus, fecal calcium and calcium-phosphorus balance. J. Clin. Invest., 1950, 29, 1167.

3. Howard, J. E., Hopkins, T. R., and Connor, T. B., On certain physiologic responses to intravenous injection of calcium salts into normal, hyperparathyroid, and hypoparathyroid persons. J. Clin. Endocrinol. \& Metab., 1953, 13, 1.

4. Hiatt, H. H., and Thompson, D. D., The effects of parathyroid extract on renal function in man. J. Clin. Invest., 1957, 36, 557.

5. Thompson, D. D., and Hiatt, H. H., Renal reabsorption of phosphate in normal human subjects and in patients with parathyroid disease. J. Clin. Invest., 1957, 36, 550.

6. Bonsnes, R. W., and Taussky, H. H., On the colorimetric determination of creatinine by the Jaffe reaction. J. Biol. Chem., 1945, 158, 581.

7. Duncan, L. E., Jr., Mirick, G. S., and Howard, J. E., Total intravenous alimentation: its effect on mineral and bacterial content of feces. Bull. Johns Hopkins Hosp., 1948, 82, 515.

8. Goldman, R., and Bassett, S. H., Effect of intravenous calcium gluconate upon the excretion of calcium and phosphorus in patients with idiopathic hypoparathyroidism. J. Clin. Endocrinol. \& Metab., 1954, 14, 278.

9. Thompson, D. D., and Hiatt, H. H., Effects of phosphate loading and depletion on the renal excretion and reabsorption of inorganic phosphate. J. Clin. Invest., 1957, 36, 566.

10. Chen, P. S., Jr., and Neuman, W. F., Renal excretion of calcium by the dog. Am. J. Physiol., 1955, 180, 623.

11. Hastings, A. B., and Huggins, C. B., Experimental hypocalcemia. Proc. Soc. Exper. Biol. \& Med., 1933, 30, 458.

12. Hopkins, T., Howard, J. E., and Eisenberg, H., Ultrafiltration studies on calcium and phosphorus in human serum. Bull. Johns Hopkins Hosp., 1952, 91, 1.

13. Foulks, J. G., Homeostatic adjustment in the renal tubular transport of inorganic phosphate in the dog. Canad. J. Biochem. \& Physiol., 1955, 33, 638.

14. Schilling, A., and Laszlo, D., Rate of urinary calcium excretion following its intravenous administration as an indicator of bone metabolism. Proc. Soc. Exper. Biol. \& Med., 1951, 78, 286. 